\title{
NOVÁ REKONSTRUKCE POHŘEBNÍHO ODĚVU RUDOLFA I. (IV.) HABSBURSKÉHO, ZVANÉHO KAŠE
}

\author{
MILENA BRAVERMANOVÁ - HELENA BŘEZINOVÁ - PETR VODA
}

\begin{abstract}
Abstrakt: Pohřební oděv českého krále Rudolfa I. (IV.) Habsburského († 1307) byl vyjmut z tumby v královské kryptě v katedrále sv. Vita na Pražském hradě v roce 1991. Poté byl restaurován v Abegg-Stiftung v Riggisbergu. Roucho bylo ušito ze dvou podobných lampasů středoasijské provenience z přelomu 13. a 14. století, vzor byl vytkán útky z proužků živočišného podkladu (küže) z vnějši strany pozlacených a z vnitřní postříbrených. První látka je vzorována motivem ptáků držicích v zobáku větévku nebo rybu, druhá pak činskými draky a obláčky. Z těchto látek bylo v roce 1995 rekonstruováno kompletni mužské oděni - plášt' s vlečkou, surcot bez rukávů a krátký vypasovaný kabátec. Surcot a kabátec mély podšivky. Problémem je, že tato rekonstrukce neodpovídá módè, která se na začátku 14. století v Evropé nosila, nástup takového oděni se datuje až do 30. let 14. století. Též střih surcotu je netypický. Proto se autoři tohoto článku pokusili o novou rekonstrukci střihu, přičemž pracovali s dokumentací pořizenou při restaurování v Abegg-Stiftung $v$ Riggisbergu. Podle nových závěrů byl Rudolf I. do rakve oděn do pláště z látky s draky a obláčky, do vypodšivkovaného oděvu s rukávy z tkaniny s ptáky a do dlouhých nohavic z látky s draky a obláčky. Pro ověreni nové teorie byla ušita napodobenina oděvu.
\end{abstract}

Klíčová slova: Pražský hrad - Rudolf I. (IV.) Habsburský - plášt'-surcot - cotte - nohavice - archeologický textil.

\section{New reconstruction of the funeral attire of Rudolf I (IV) of Habsburg, called Kaše}

Abstract: The funeral garments of Czech King Rudolf I (IV) of Habsburg ( +1307$)$ were removed from his tomb in the royal crypt in St. Vitus' Cathedral at Prague Castle in 1991. They were then restored by the Abegg-Stiftung company in Riggisberg. The attire consisted of two similar lampas fabrics of central-Asian provenance from the 13th/14th century. The patterns were woven by wefts made up of strips of animal origin (leather) gilded on the outside and silver-plated on the inside. The first fabric has a pattern with the motif of birds holding a twig or fish in their beaks, the other features Chinese dragons and clouds. Complete male attire was reconstructed from these fabrics in 1995: a cloak with a trail, a sleeveless surcoat and a short tight jacket. The surcoat and the jacket had a lining. However, this reconstruction does not correspond to fashion in Europe in the early 14th century as this kind of clothing is only reported from the 1330s onwards. The cut of the surcoat is not typical, either, which is why the authors carried out a new reconstruction, working with the documentation made during the restoration in the Abegg-Stiftung workshop in Riggisberg. New conclusions show that Rudolf I was dressed in a cloak made of the fabric with dragons and clouds, a garment with sleeves and a lining made of the fabric with birds, and in hose of the fabric with dragons and clouds. A replica of the clothing was made to test this new theory.

Key words: Prague Castle - Rudolf I (IV) of Habsburg - cloak - surcoat - cotte - hose - archaeological textile.

\section{1 Úvod}

Pohřební oděv českého krále Rudolfa I. (IV.) Habsburského († 1307), zv. Kaše, byl vyzvednut z tumby v královské kryptě v katedrále sv. Víta na Pražském hradě v roce 1991 (Praha, Sbírky Pražského hradu, inv. č. PHA 49). Zachované textilie byly ve fragmentárním stavu v nepůvodní poloze, nebot' obsah hrobu byl v minulosti několikrát přenášen (k nálezovým okolnostem podrobně viz Bažantová et al. 1993). Stav zachování textilií a pozice jednotlivých oděvních součástí nejsou z dostupné dokumentace patrné. V roce 1995 byly tkaniny restaurovány v Abegg-Stiftung - centru nadace Wernera Abegga v Riggisbergu ve Švýcarsku.

V rámci konzervátorsko-restaurátorského zásahu byl rekonstruován domnělý tvar původního oděvu, který vycházel ze studia jednotlivých textilních fragmentů, a to z textilně technologického rozboru, rekonstrukce vzoru, zjištění původních krejčovských stop a pozorování barevných odlišností. V restaurátorské zprávě bylo konstatováno, že zbytky textilií se nacházely ve velmi špatném stavu a neposkytují tak jednoznačný obraz o původních částech oděvu 
(Flury-Lemberg-Illek 1995, 174-199; 1995a). Jednotlivé části oděvu - svrchní vzorované tkaniny i podšívky - byly rozloženy na dřevěných panelech obalených speciální tkaninou. Místa, kde se nedochoval originální textilní materiál, ale dal se předpokládat jeho původní tvar, byla znázorněna pomocí průsvitné restaurátorské látky, tzv. krepelíny. Panely byly zakryty sklem. Na závěr byla pořízena šitá rekonstrukce všech částí původního oděvu - pláště, surcotu a kabátce, a to z textilie, na kterou byly vzory naneseny metodou sítotisku.

Poznatky z průzkumu, restaurování či interpretace byly několikrát publikovány, textilie byly také vystavovány (Bažantová et al. 1993, 359-377; Bravermanová 1996; 1997, 67-84; 2010, 307-309; Flury-Lemberg-Illek 1995, 174-199; Bravermanová-Flury-Lemberg 2004, 295-298).

Při následném vyhodnocení rekonstrukce oděvu se však ukázalo, že vytvořený vzhled oděvu neodpovídá zcela písemným a obrazovým pramenům vztahujícím se k módě začátku 14. století (k tomu Bravermanová 1997) a na lidskou postavu je nepadnoucí (ověřeno experimentálně P. Vodou). O pochybnostech nad řešením střihu bylo poměrně široce diskutováno mezi odborníky zabývajícími se historickou módou, a to nejen v Čechách, ale i v zahraničí. Proto došlo k vypracování návrhu nového řešení stř̌ihové konstrukce (Bravermanová-Voda 2011) a následně $\mathrm{k}$ pokusu o novou rekonstrukci podoby roucha. Ta byla prezentována jednak na mezinárodní konferenci o archeologickém textilu NESAT XIII 2017 (Bravermanová-Voda 2017, 349), jednak na popularizačním semináři k historii odívání v Hradci Králové (Voda 2017, 51-71).

Dochované pozůstatky pohřebního roucha Rudolfa I. jsou závažným dokladem středověké módy, který budí zaslouženou pozornost mezi odbornou i laickou veřejností. Je proto velmi potřebné zveřejnit podrobněji novou interpretaci, širší argumentaci a výsledné zdůvodnění.

\section{Shrnutí dřívější interpretace}

Roucho bylo ušito ze dvou technologicky obdobných hedvábných lampasů (v základu je vždy plátnová vazba, ve vzoru bud' kepr $2 / 1 \mathrm{~S}$ anebo kepr $2 / 1 \mathrm{Z}$ ). Jejich vzor byl vytvořen útky z proužků živočišného podkladu (kůže) z vnější strany pozlacených a z vnitřní strany postř́ibřených. První látka je vzorována souvislými řadami vodních ptáků s rozepjatými křídly a stř́idavě otočenými hlavami skloněnými k zemi, držících v zobáku větévku nebo rybu (obr. 1). Druhá tkanina je vytkána do vzoru s pravidelně se opakujícím motivem čínských draků a obláčků (obr. 2). Podle průzkumu původní barevnosti provedeného v rámci restaurování měly obě látky zřejmě př́rodní světlou barvu. Byly utkány ve Střední Asii na přelomu 13. a 14. století, roucho tedy bylo ušito z luxusních importů ze vzdálených oblastí (ke tkaninám středoasijského původu podrobněji viz Bravermanová 2016, 78-114).

Podle dřívější interpretace oděv tvořil polokruhový plášt' ušitý ze čtyř pruhů látky s draky a obláčky, položených vertikálně, přičemž vzor dvou sousedních pruhů směřuje dolů a druhých dvou sousedních pruhů nahoru (obr. 3a). Do vlečky pláště byly z rubu vloženy dva menší pruhy tkaniny s ptáky (č. fragm. 1, 2; obr. 3b). Krátký surcot délky nad kolena a bez rukávů byl vytvořen ze tří dílů. Úzký lichoběžníkový díl na zádech byl z látky s ptáky (č. fragm. 4), naopak zbylé dva díly s úzkým kapkovitým průramkem (č. fragm. 3,5), které tvořily zároveň boky a předek oděvu, byly z látky s draky a obláčky. Tyto dva díly byly ale střiženy tak, že vzor směřoval na jednom díle dolů a na druhém nahoru (obr. 4). Krátký vypasovaný kabátec byl pořízen z látky s ptáky (č. fragm. 6, 7, 8, 9, 13,14). Do úzkých obloukovitě tvarovaných průramků byly vloženy rukávy (č. fragm. 10,11,12), avšak s hlavicí lichoběžníkového tvaru, vpasování do průramku měl zajištovat nepravidelný lichoběžníkový klínek (č. fragm. 15; obr. 5). Surcot i kabátec měly podšívku ze shodné hedvábné tkaniny v plátnové vazbě (obr. 6), plášt' podšívku neměl.

\section{Problematičnost dřívější rekonstrukce jednotlivých oděvních částí}

Nejrozměrnějším předmětem je plášt' s vlečkou z tkaniny s draky a obláčky. Čtyři pruhy látky o šiřce zhruba $92 \mathrm{~cm}$, což podle zachovaných pevných okrajů odpovídá původní šíři tkaniny, byly položeny vedle sebe tak, že po zastřižení vytvořily polokruhový tvar. Tato interpretace 


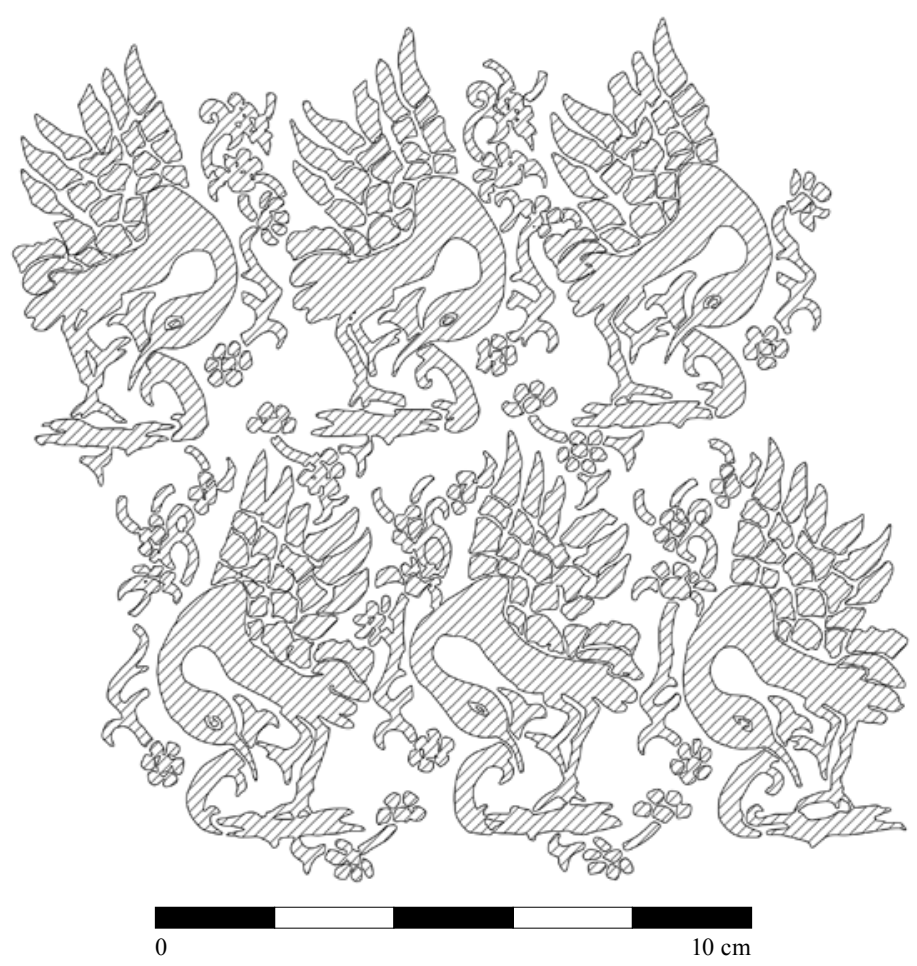

Obr. 1. Rozkres vzoru látky s ptáky. Kresba A. Samohýlová; grafická úprava K. Vytejčková.

Abb. 1. Detailzeichnung des Stoffmusters mit Vögeln. Zeichnung A. Samohýlová; grafische Gestaltung K. Vytejčková.

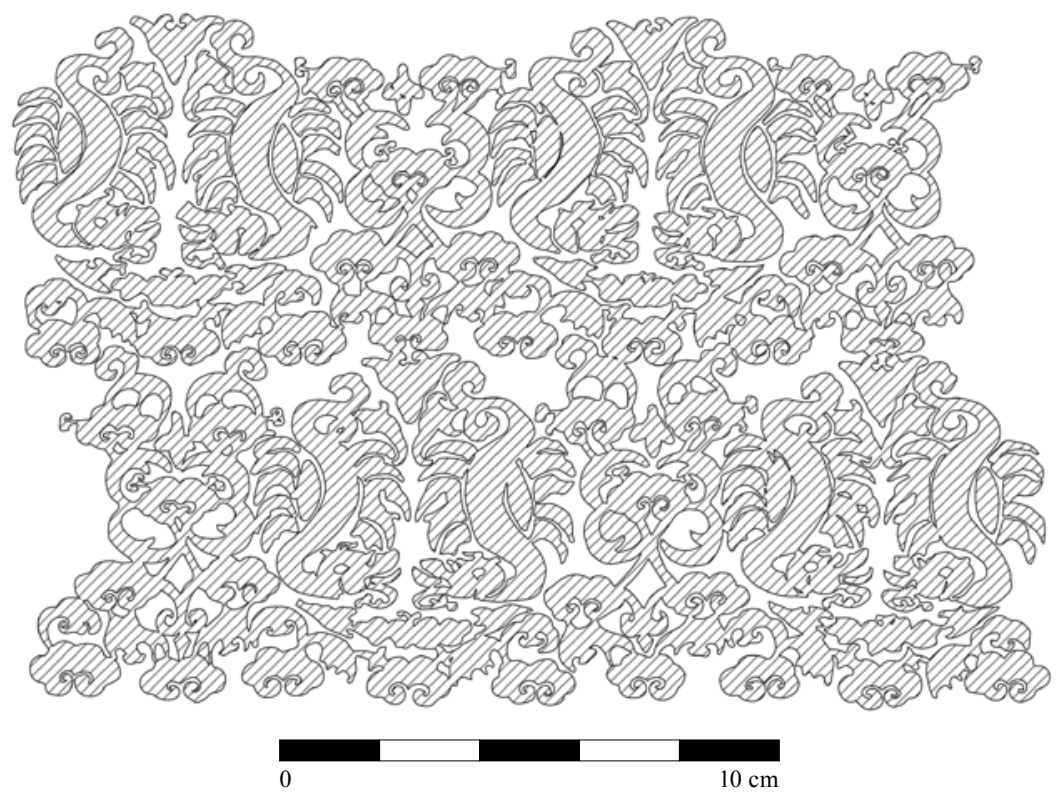

Obr. 2. Rozkres vzoru látky s draky a obláčky. Kresba A. Samohýlová; grafická úprava K. Vytejčková.

Abb. 2. Detailzeichnung des Stoffmusters mit Drachen und Wölkchen. Zeichnung A. Samohýlová; grafische Gestaltung K. Vytejčková. 

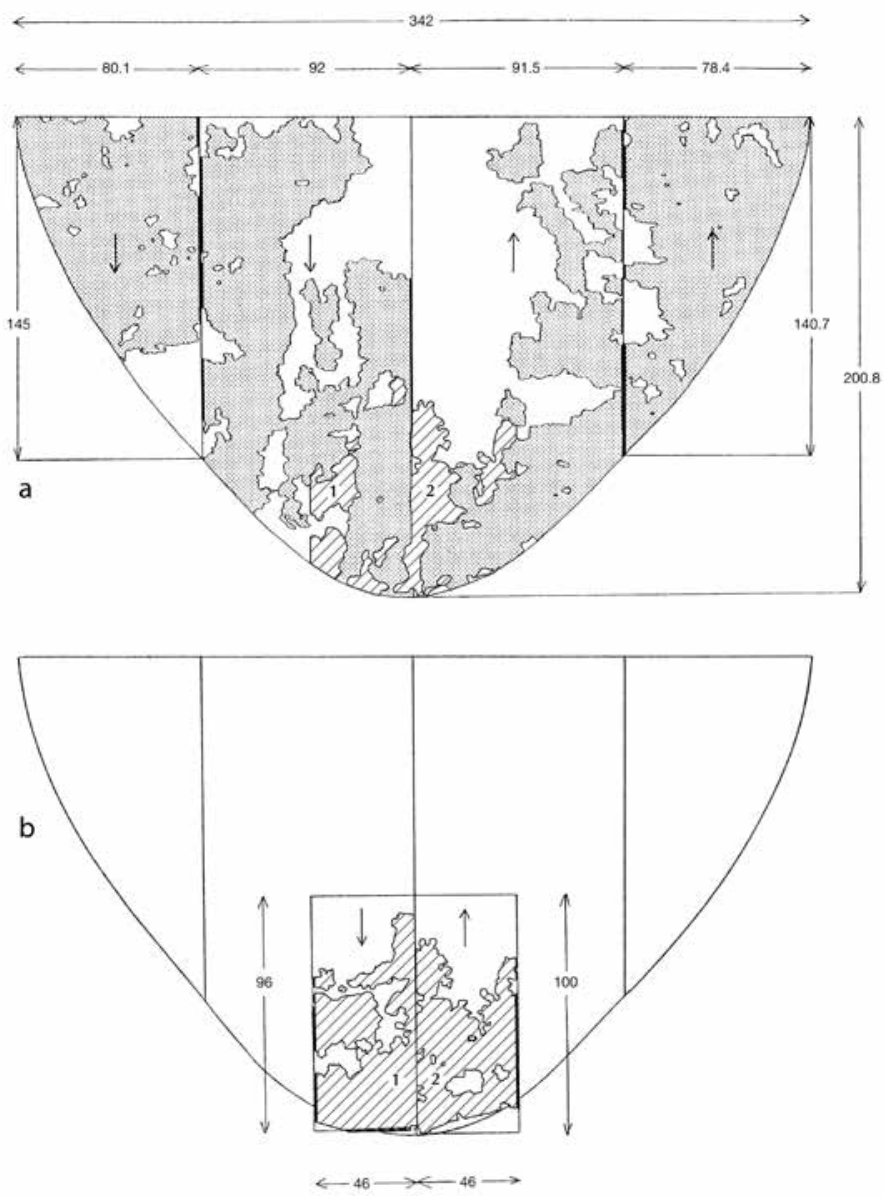

Obr. 3. Plášt'. a - dřívější interpretace tvaru pláště s jednotlivými fragmenty tkanin, tečkovaně - látka s draky a obláčky, šrafurou - látka s ptáky; b - vložené dva díly látky s ptáky; čísla fragmentủ odpovídají číslům používaným v textu. Podle Flury-Lemberg-Illek 1995, 197.

Abb. 3. Mantel. a - frühere Interpretation der Mantelform mit einzelnen Stoffragmenten, gepunktet - Stoff mit Drachen und Wölkchen, schraffiert - Stoff mit Vögeln; b - eingefügte zwei Stoffteile mit Vögeln; die Ziffern entsprechen den im Text für die Fragmente benutzten Ziffern. Nach Flury-Lemberg-Illek 1995, 197.

neodporuje znalostem o dobové módě. Problematické však bylo vložení dvou dílů z látky s ptáky (č. fragm. 1,2) do rubu vlečky tak, že líc této tkaniny je opačně, než je líc tkaniny celého pláště. Na základě studia kresebné dokumentace i pozorováním originálu se potvrdilo podezření, že pro dosažení zaobleného průběhu okraje vlečky byly při rekonstrukci oba díly částečně založeny, nebot' se na nich původně žádné zaoblení nenacházelo (obr. 3b).

Surcot byl vytvořen ze tří dílů z obou látek - zadní byl z látky s ptáky (č. fragm. 4), boční díly tvořící i předek byly z látky s draky a obláčky (č. fragm. 3, 5). Každý díl však byl střižen opačně. Tato konstrukce je netypická. Tvar průramků byl pro protažení mužské paže velmi těsný. Hluboký výstřih tvaru $\mathrm{V}$ nemá v obrazových pramenech žádnou oporu, při nošení by se navíc oděv rozevíral a padal z ramen. Délka pouze ke kolenům opět není v obrazových ani písemných pramenech zachycena, na začátku 14. století mužské oděvy nejvyšších vrstev společnosti sahaly minimálně do půli lýtek ( $\mathrm{k}$ tomu Bravermanová 1997). 


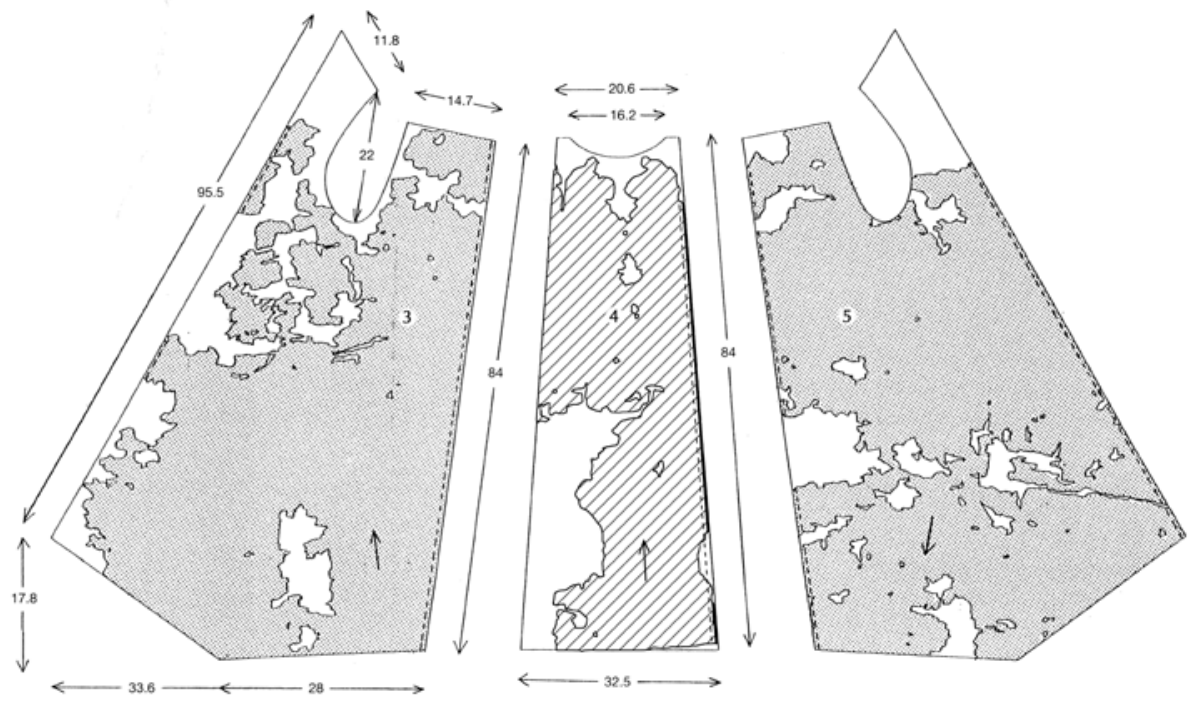

Obr. 4. Dř́ívější interpretace tvaru surcotu s jednotlivými fragmenty tkanin; čísla fragmentů odpovídají číslům používaným v textu. Podle Flury-Lemberg-Illek 1995, 199.

Abb. 4. Alte Interpretation der Surcotform mit einzelnen Stofffragmenten; die Ziffern entsprechen den im Text für die Fragmente benutzten Ziffern. Nach Flury-Lemberg-Illek 1995, 199.

Kabátec z látky s ptáky byl po rekonstrukci krátký a vypasovaný, což se rovněž v ikonografických pramenech nenalézá, nástup této módy je datován nejdřive do 30. let 14. století (více viz oddíl 7). Projmutí o $8 \mathrm{~cm}$ bylo navíc provedeno jenom na zadním díle, díly přední byly po straně střiženy rovně, což by při sešití $\mathrm{k}$ sobě způsobilo nežádoucí nařasení. Zadní díl se skládal z několika fragmentů. První tvořil ramena a záda (č. fragm. 6), druhý, malý, šel od průramku směrem k pasu (č. fragm. 7). Na něj navázal velký fragment obdélníkového tvaru s patrnými rovnými okraji (č. fragm. 8). Tato část tvořila partii okolo pasu, na níž bylo zmíněné projmutí. Na obdélníkový fragment navázal v části boků menší (č. fragm. 9), který jak v kresebné dokumentaci, tak na originále vypadal, jako by byl součástí velkého fragmentu, o čemž však autoři nového řešení stř̌ihové konstrukce měli pochybnosti. Kabátec měl vzadu rozparek, rekonstruovaný na základě dochované podšívky (č. fragm. 16). Průramek byl určen nahodile, nebot' látka s ptáky se v těchto místech nedochovala. Argument, že k odvození tvaru průramku přispěl tvar podšívky, se při nové rekonstrukci ukázal jako nedostatečný, nebot' ani podšívka tento tvar neměla. Navíc do obloukovitě tvarovaného průramku byl vložen rukáv s lichoběžníkovou hlavicí doplněný v podpaží malým lichoběžníkovým klínkem (č. fragm. 15). Nově se experimentálně ukázalo, že hlavice rukávů a průramku spolu tvarově ani rozměrově nesedí a vytvořené míry jsou navíc natolik malé, že by tato partie byla velmi těsná.

Zachované fragmenty podšívek byly rozloženy na jednom společném panelu, měly patřit k surcotu i ke kabátci. Byly zhotoveny z totožné tkaniny. Na panelu byl pomocí krepelíny vyznačen základní tvar oděvů, tak jak byl rekonstruován, a do něj byly vloženy různé fragmenty, aby tomuto tvaru odpovídaly. Velmi často je k sobě těsně přisazeno několik fragmentů s rovnými okraji, což postrádá logické vysvětlení (obr. 6).

\section{Pracovní metody při získávání podkladů pro novou rekonstrukci}

Přímo s originálními fragmenty oděvů nebylo nyní z organizačně-finančních důvodů umožněno pracovat. Jako základní metoda pro získání podkladů, s nimiž bylo možné se pokusit 

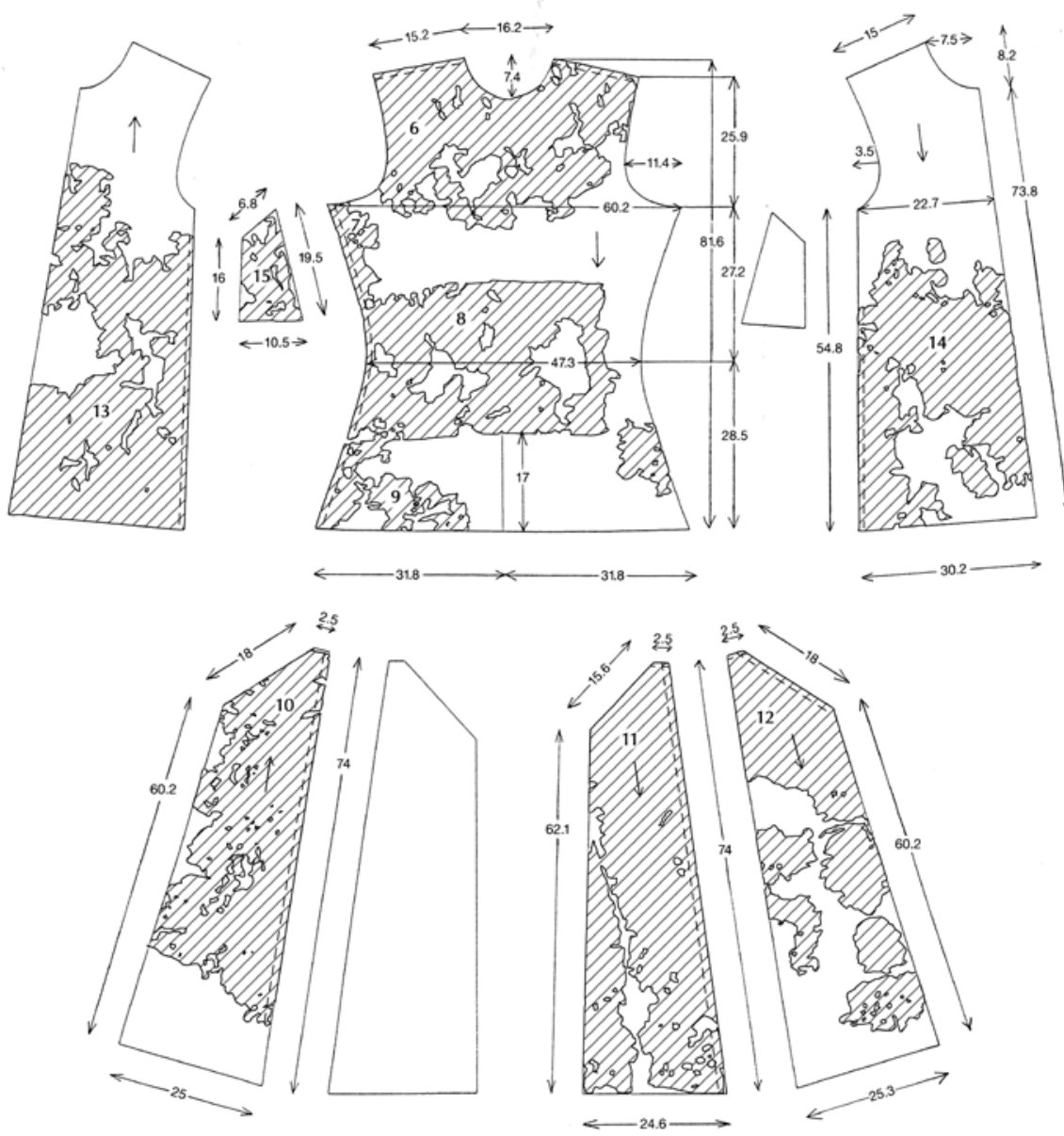

Obr. 5. Dřívější interpretace tvaru kabátce s jednotlivými fragmenty tkanin; čísla fragmentů odpovídají číslům používaným v textu. Podle Flury-Lemberg-Illek 1995, 198.

Abb. 5. Frühere Interpretation der Wamsform mit einzelnen Stofffragmenten; die Ziffern entsprechen den im Text für die Fragmente benutzten Ziffern. Nach Flury-Lemberg-Illek 1995, 198.

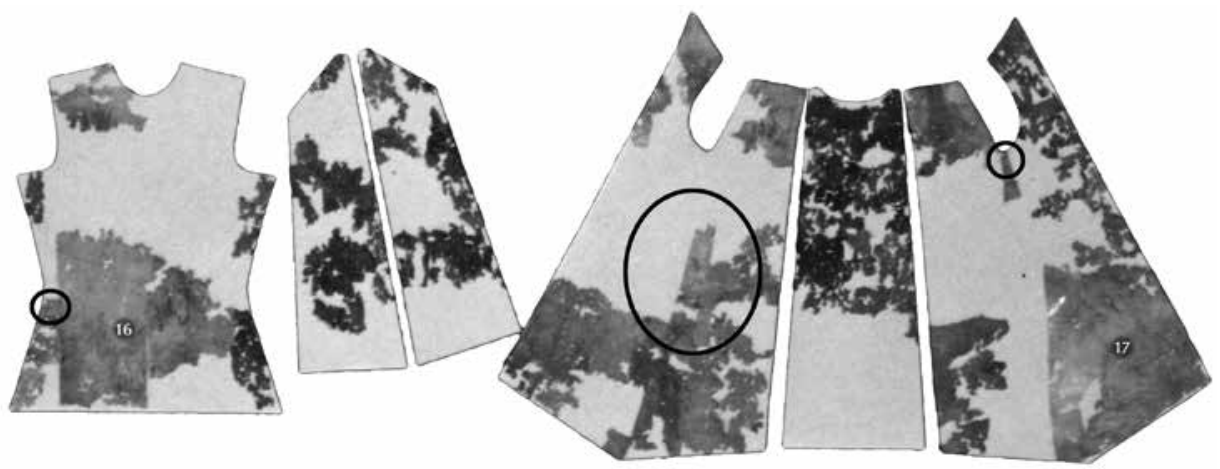

Obr. 6. Panel s podšívkami s vyznačením míst, kde jsou k sobě těsně přisazeny fragmenty s rovnými okraji; čísla fragmentů odpovídají číslủm používaným v textu. Podle Flury-Lemberg-Illek 1995a.

Abb. 6. Tafel mit Futter und eingezeichneten Stellen, an denen Fragmente mit geradem Rand eng aneinander angestückt wurden; die Ziffern entsprechen den im Text für die Fragmente benutzten Ziffern. Nach Flury-Lemberg-Illek 1995a. 
vypracovat novou podobu oděvu, bylo proto zvoleno využití fotografické a kresebné dokumentace jednotlivých fragmentů pořízené při restaurování v Abegg-Stiftung (Flury-Lemberg-Illek 1995a). Problémem je, že dokumentace je staršího data, fotografie jsou v černobílém provedení a také zpráva je z dnešního pohledu v některých úsecích málo podrobná. Například na kresbách jednotlivých rekonstruovaných oděvních částí z pohledu shora jsou údajně zachyceny tvary jednotlivých dochovaných fragmentů, leckdy ale není zřejmé, zda jsou takto zachyceny všechny jednotlivé fragmenty, nebo se jedná až o výslednou podobu vzniklou při rekonstrukci. Skutečná dokumentace všech fragmentů, kdy každý fragment má samostatnou kresbu, v restaurátorské zprávě chybí. Proto jsme se obrátili na centrum nadace W. Abegga, jmenovitě na R. Schortu, s dotazem, zda není v restaurátorské dílně v Riggisbergu ještě uložena další dokumentace. Ukázalo se, že kresebné podklady zde uchovávané jsou prakticky totožné s těmi, které se nacházejí ve zmenšené podobě v restaurátorské zprávě, z čehož vyplývá, že kresby jednotlivých fragmentů již neexistují. Byla nám ale poskytnuta dosud neznámá, avšak zásadní, fotografie dokládající, že velký fragment obdélníkového tvaru na zádech kabátce, na nějž jako by navazovala menší část směrem $\mathrm{k}$ boku, sestává ze dvou původně samostatných fragmentů, daných těsně $\mathrm{k}$ sobě až při dřívější rekonstrukci (obr. 7).

Dále proběhlo pozorování originálů tkanin, které však bylo značně ztíženo tím, že tyto jsou uloženy pod sklem s několikamilimetrovou tloušt'kou, což při pohledu shora způsobuje zkreslení. Zkoumány byly hlavně ty části, u nichž se předpokládalo nahodilé sesazení fragmentů; zajímalo nás, zda se například skutečně jednalo o jeden větší fragment, anebo původně šlo o fragmentů více. Pomocí nasvícení a práce s lupou, i když přes sklo, byl učiněn pokus ověřit přesný tvar určitých fragmentů. V některých případech se podezření, že jsou fragmenty složeny $z$ více částí, jejichž okraje byly vloženy jeden pod druhý, potvrdilo. Podle dřívější rekonstrukce byly fragmenty podšívek $\mathrm{z}$ totožné hedvábné tkaniny v plátnové vazbě přiřazeny $\mathrm{k}$ surcotu a ke kabátci. Při nové rekonstrukci se vzhledem ke shodnému materiálu s fragmenty pracovalo tak, jako by se původně jednalo o podšívku jednu.
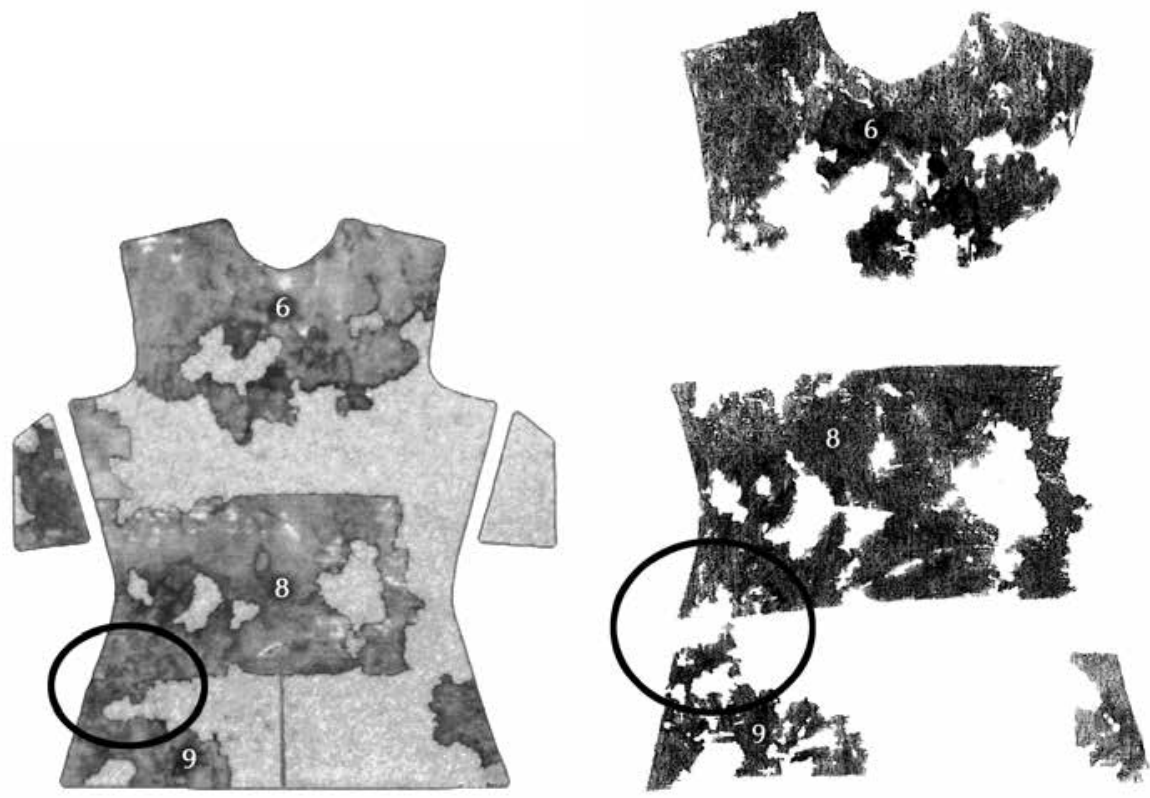

Obr. 7. Kabátec. a - detail domnělé části kabátce, kde jsou dva samostatné fragmenty k sobě přisazeny tak, že vypadají jako jeden fragment; b - fotografie dokládající, že na zádech domnělého kabátce byly k sobě přiloženy dva samostatné fragmenty. Foto Abegg-Stiftung.

Abb. 7. Wams. A - Detail des mutmaßlichen Wamsteils, an dem zwei selbständige Fragmente so aneinander angestückt wurden, dass sie wie ein Fragment aussehen; b - Foto, das belegt, dass auf dem Rücken des mutmaßlichen Wamses zwei selbständige Fragmente aneinander angestückt wurden. Foto Abegg-Stiftung. 
Poté byly z papíru vystřiženy tvary všech jednotlivých rozeznatelných fragmentů vzorovaných látek i podšívky ve skutečné velikosti. Každý takovýto papírový model dostal vlastní označení a bylo na něm zakresleno, v jakém směru byla tkanina střižena, přesné průběhy okrajů, pevné okraje, stopy po stříhání, záložky, ohyby a dírky po stezích (obr. 8).

Hlavním vodítkem pro uspořádání jednotlivých dílů při nové rekonstrukci se staly střižené rovné okraje fragmentů, a to jak u vzorovaných látek, tak u podšívky, nebot' u nich lze předpokládat, že se jedná o skutečný pozůstatek původního střihu. Na řadě fragmentů se střižené okraje sbíhají, svírajíce spolu určitý úhel, pokud je zachován střižený okraj jen jeden, svírá určitý úhel s útkem. Fragmenty se stejnými úhly střihu mohly tedy patřit kdysi stejnému oděvnímu dílu,
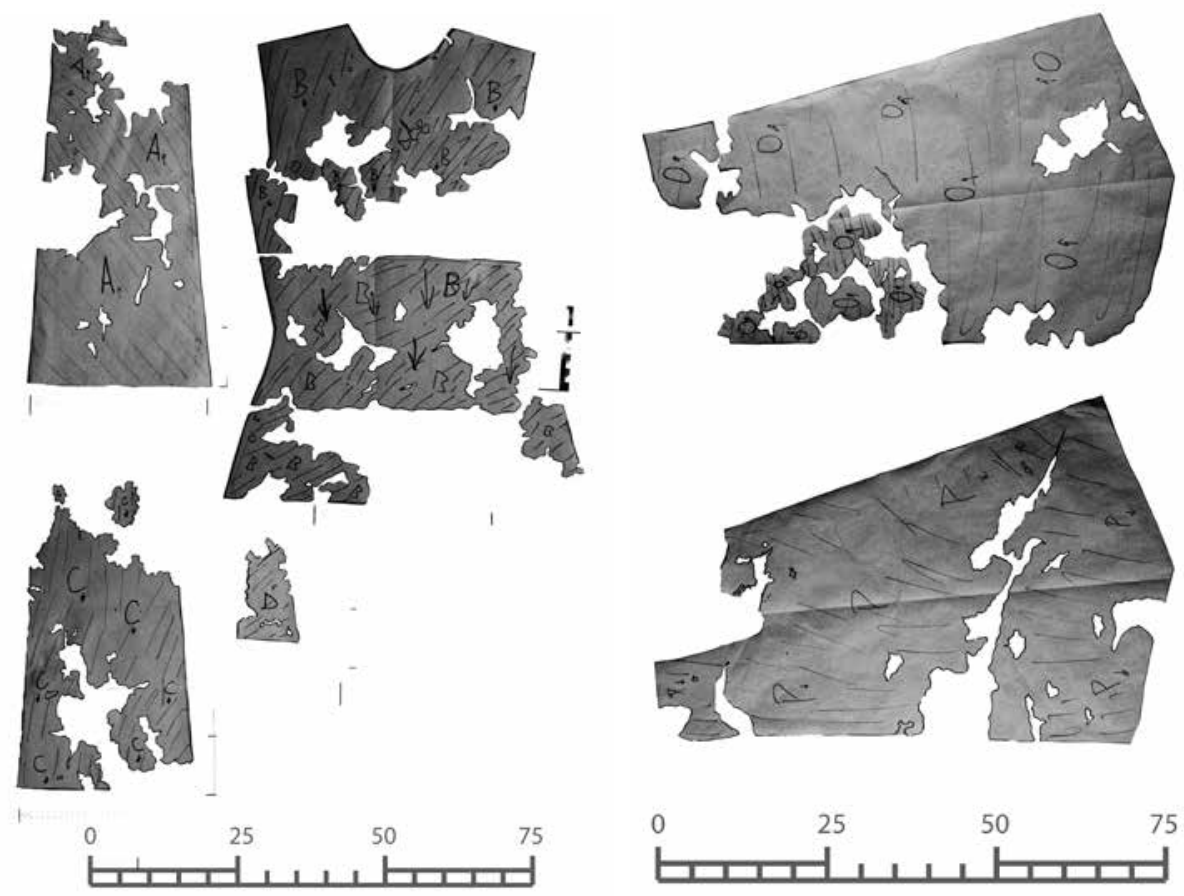

Obr. 8. Papírové modely jednotlivých fragmentů během přípravy nové interpretace. Foto P. Voda. Abb. 8. Papiermodelle der einzelnen Fragmente während der Vorbereitung der neuen Interpretation. Foto P. Voda.

a to jak u vzorovaných látek, tak u podšívky. Tento předpoklad je klíčem celé nové interpretace a umožňuje doplnit tvar oděvních dílů ze vzorovaných látek tvarem dílů podšívky.

Výsledná podoba nové rekonstrukce oděvu byla ověřena pomocí obrazových pramenů, srovnáním s dochovanými stř̌edověkými oděvy i experimentálně vytvořením šité rekonstrukce.

\section{Nová interpretace jednotlivých oděvních částí}

\subsection{Plášt'}

Tvar a střih pláště zůstal beze změn. Měl tedy poloeliptický tvar složený ze čtyř vertikálně položených pruhů z látky s draky a obláčky, které byly v oblasti vlečky obloukovitě střiženy. Do vlečky však žádná jiná tkanina vložena nebyla. Dva přebývající pruhy látky s ptáky (č. fragm. 
1, 2) nejsou na konci střiženy do oblouku, tak jako ostatní díly, a proto byly využity při rekonstrukci jiné oděvní části. Plášt' je bez podšívky a krejčovsky ledabyle zpracován.

Rozměry: největší výška 200 cm; největší šiřka $342 \mathrm{~cm}$.

Polokruhový či poloeliptický plášt' byl součástí ceremoniálního oděvu nejvyšších společenských vrstev, patřil i ke korunovačnímu rouchu (např. Kania 2010, 176-184; Pilná 2017, 114115). Panovníci v něm byli často zobrazováni, např́íklad Přemysl Otakar I. na reliéfu z původního vstupu do baziliky sv. Jiří (začátek 13. století, Praha, Sbírky Pražského hradu) či Jindřich VII. při své korunovaci, ale i na smrtelném loži, v Codexu Balduini Trevirensis (fol. 9, 35; okolo 1340, Koblenz, Landeshauptarchiv).

Polokruhový plášt' se dochoval jako součást pohřebního roucha Karla IV. († 1378) či zřejmě Elišky Pomořanské († 1393) z královské krypty v katedrále sv. Víta na Pražském hradě (obojí Praha, Sbírky Pražského hradu; naposledy Bravermanová 2016, 94, 104). Na pohřebišti Štaufů v katedrále ve Špýru v něm byl do rakve uložen Filip Švábský († 1208, Špýr, Kaiserdom St. Maria und Stephan; Herget 2011, 197-201). Též tvořil součást pohřebních oděvů králů Leonu a Kastilie a jejich př́buzných v klášteře v Burgosu, a to Alfonsa VIII. († 1214), Fernanda de la Cerda († 1275) a syna Alfonsa X. Fernanda (ca 1250; vše Burgos, Santa Maria la Real de Huelgas; Luaces-Valle Pérez 2005, 154-155, 157-175).

\subsection{Oděv s rukávy}

Nová podoba oděvu s rukávy byla vytvořena pouze z fragmentů látky se vzorem ptáků. Na nich, ale i na podšívce, se dochovaly stopy po pečlivém krejčovském zpracování - záložky a vpichy po stezích, což svědčí o tom, že oděv byl dobře zpracován (obr. 9).

Nejprve byl určen tvar předního a zadního dílu. Jednoznačný byl zpočátku jenom velký fragment (č. fragm. 6), na němž se zachoval průkrčník, část ramen a průramky. Tím byla zhruba dána šířka pruhů, které podle dobové módy tvořily základ předního a zadního dílu. Díl se zachovalým průkrčníkem byl určen jako zadní, protože zahloubení průkrčníku bylo mělké. Pokud by i druhý díl měl shodné zahloubení, obvod průkrčníku by byl jenom asi $50 \mathrm{~cm}$, což je na prostrčení hlavy poměrně málo. Přední, v této partii nedochovaný díl tedy musel mít průkrčník hlubší, případně rozparek. Do plochy předního a zadního dílu byly umístěny dva poměrně velké fragmenty (č. fragm. 1, 2), které v dřívější rekonstrukci byly použity do vlečky pláště a mají stejnou šířku. Velmi důležitý byl i fragment podšívky s rozparkem (č. fragm. 16), bylo zřejmé, že je možno jej umístit někam na přední či zadní díl zhruba do výšky stehen. Nakonec byl umístěn na přední díl a do rozparku, který musel být původně delší, se vložily dva malé trojúhelníkové klínky, jejichž tvar je zachován v podšívce.

Tři fragmenty vzorované látky mají „ut’atou špičku“ a stejný úhel zešikmení rovně střižených okrajů (č. fragm. 10,11, 12). Po doplnění několika fragmenty podšívky a po pomyslném protažení okrajů pod daným úhlem byly rekonstruovány čtyři klíny, které z každé strany navázaly na přední a zadní díl oděvu (č. fragm. 10,11,12,13). Jejich protažené okraje přesně navazují na základnu se stejným úhlem hran a chybějící horní částí, takže bylo možno určit jejich délku. Mezi ně byly umístěny vždy jeden a jeden další klín (č. fragm. 4, 14), který měl jiný úhel zešikmení rovně střižených okrajů (byl symetrický podle středové osy). Oděv tedy měl na každém boku trojici klínů, dva delší se zešikmeným horním okrajem a jeden střední, kratší, s rovným horním okrajem. Je však otázkou, zda malé trojúhelníkové klíny, nyní umístěné do rozparku, nemohly být vsazeny někde mezi bočními klíny.

Základ jednoho rukávu vytvořil velký obdélníkový fragment na jedné straně s prohloubeninou (č. fragm. 8), tedy ten, který byl při dřívější rekonstrukci umístěn na kabátci v partii pasu. Prohloubenina byla nyní dána do podpaží. Do druhého rukávu byl rovněž použit fragment z bývalého těla kabátce (č. fragm. 9). Zbývalo umístit několik fragmentů podšívky, jejichž okraje se sbíhaly pod ostrým úhlem. Protože byla známa velikost průramku a podle dobové módy se rukávy k zápěstí mohly zužovat, byly tyto fragmenty umístěny tak, že vytvořily dva a na druhém rukávu opět dva díly okolo středového dílu s prohloubeninou. Zásadní byl především poměrně 


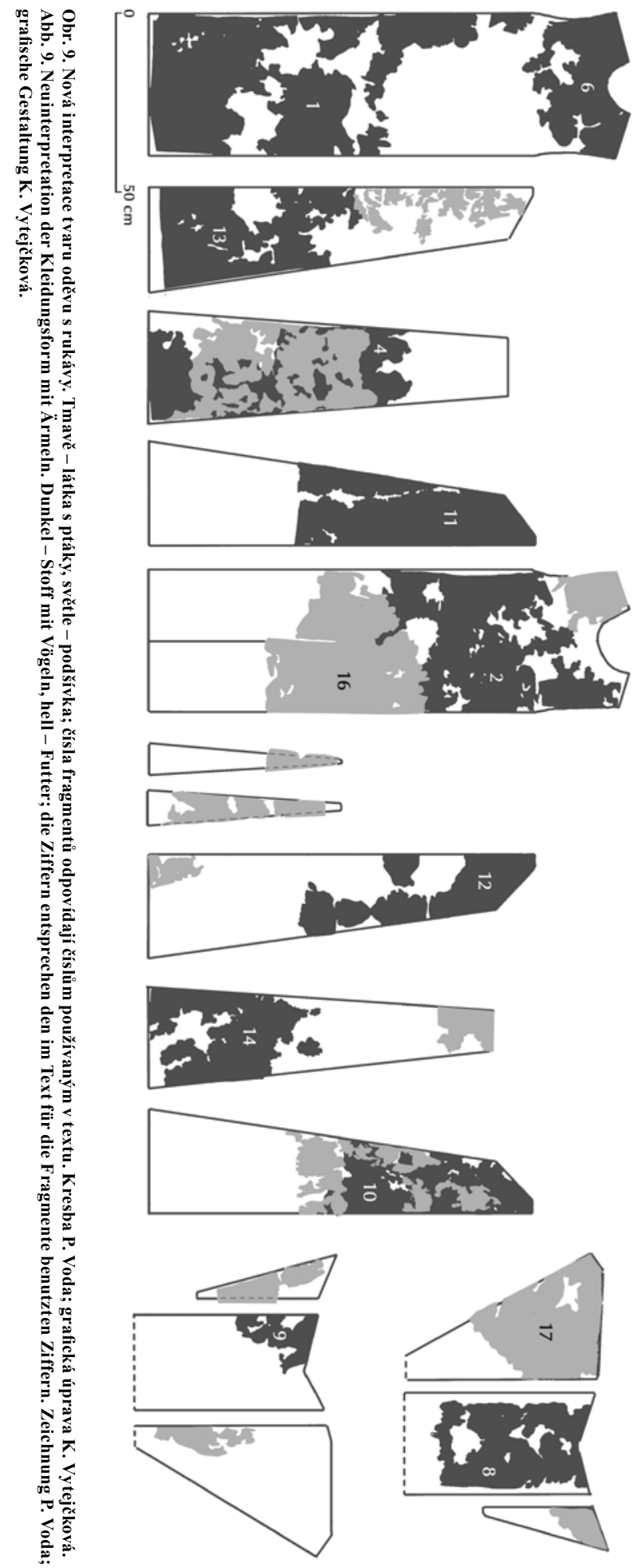




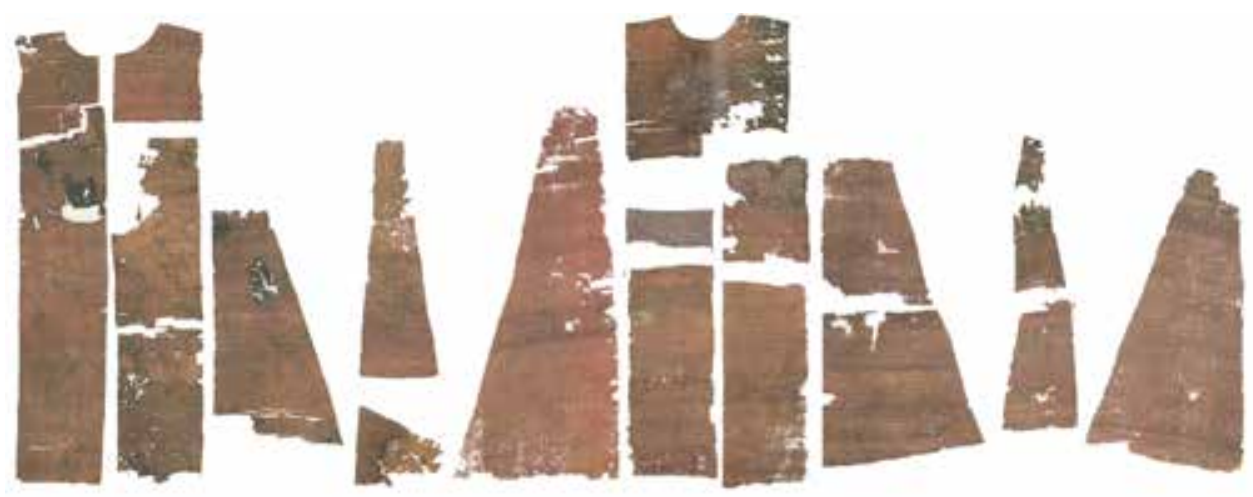

Obr. 10. Tunika s dlouhým rukávem Cangrande della Scala. Podle Marini-Napione-Varanini 2005, 25, upravil P. Voda. Abb. 10. Langärmelige Tunika Cangrande della Scala. Nach Marini-Napione-Varanini 2005, 25, Bearbeitung P. Voda.

velký fragment podšívky se třemi okraji (č. fragm. 17), přičemž dva z nich se k sobě ostř̌e sbíhají. To vytvořilo zúžení směrem k zápěstí. Po sesazení těchto tř́i částí vznikla mírně tvarovaná hlavice. Délka rukávů a tím i obvod jejich dolního okraje jsou diskutabilní, zachované fragmenty vzorované látky i podšívky nedovolují stanovit, zda původně byly tříčtvrteční nebo dlouhé až k zápěstí. Protože chybí části průramků, nelze způsob sešití průramků a rukávů přesně rekonstruovat. Je možné, že rukávy nebyly zcela všity a mohly se nosit jako volně visící od ramene.

Rozměry (rekonstruované): předpokládaná délka ca $130 \mathrm{~cm}$; dolní obvod ca $260 \mathrm{~cm}$; šířka předního a zadního dílu ca $40 \mathrm{~cm}$; délka delší strany klínů s ,ut’atou špičkou“ ca $100 \mathrm{~cm}$ - délka kratší strany ca $90 \mathrm{~cm}$ - největší šiřrka ca $30 \mathrm{~cm}$; výška středního klínu ca $90 \mathrm{~cm}$ - největší šířka ca $30 \mathrm{~cm}$; obvod průramku ca $80 \mathrm{~cm}$.

Rekonstruovaný oděv s rukávy je poměrně objemný a dlouhý, což odpovídá dobové módě. Skládal se tedy ze dvou pásových dílů vpředu a vzadu s průkrčníkem, přední díl měl rozparek, do něhož byly vloženy dva trojúhelníkové klínky. Mezi předním a zadním dílem byly na každé straně vždy dva větší lichoběžníkové klíny a mezi nimi ještě jeden menší. Nahoře široké rukávy byly ze tří částí, ta s prohloubeninou byla na každé straně doplněna dalšími klínovitými díly, jedním velkým a jedním malým. Hlavice byla mírně tvarovaná, směrem k zápěstí se rukávy zužovaly.

Vzhledem k tomu, že nelze přesně zrekonstruovat délku a obvod dolního okraje rukávů, nelze stanovit, o jaký typ oděvu se přesně jednalo. Nabízejí se dvě možnosti - surcot $\mathrm{s}$ tř́ičtvrtečním rukávem, případně cotte s dlouhým rukávem.

Cotte i surcot se objevují od 12. století jako mužský i ženský oděv. Cotte (základní oděv) i surcot (svrchní oděv) byly směrem k dolnímu okraji rozšířeny klíny. Rozdíl byl v provedení rukávů, u cotte byly dlouhé a směrem k zápěstí obvykle zúžené, někdy s knofličcky. Surcot měl rukávy širší a tř́ičtvrteční délky anebo neměl rukávy vůbec. Průramky bezrukávového surcotu se postupně od 13. století prohlubovaly. Surcot se nosil přes cotte (Bravermanová 1997, 75-78; dále např. Kania 2010, 176-184; Pilná 2017, 116-117).

Oba typy oděvu jsou zachyceny i v obrazových pramenech, na vyobrazeních je mají na sobě muži i ženy. Pro dobu Rudolfa I. Habsburského je jedním z nejdůležitějších Codex Manesse (Große Heidelberger Liederhandschrift; okolo 1304, dodatky do 1340; Heidelberg, Universitätsbibliothek). Mužská cotte s dlouhými a k zápěstí se zužujícími rukávy a se středovým rozparkem je např́íklad na miniatuře Der von Kürenberg (fol. 63r). Surcoty, jeden s tříčtvrtečními širšími rukávy a druhý s volnými rukávy jenom částečně všitými do průramku, jsou např́íklad na miniatuře Der Hardegger (fol. 290r). 
Velmi obdobné střihy, jako je střih oděvu Rudolfa I., mají tunika (základní oděv) s dlouhým rukávem a svrchní oděv, které byly vedle pláště, pokrývky hlavy a dalších několika textilií součástí pohřebního roucha veronského vládce Cangrande della Scala († 1329; Verona, Museo di Castelvecchio). Oba oděvy jsou ušity z látek zhotovených ve Střední Asii. Nedochovaly se v celistvosti, jenom v samostatných fragmentech, P. Frattaroli se však pokusila o interpretaci původních tvarů (obr. 10). ${ }^{1}$ Tunika byla rekonstruována tak, že její základ tvořil přední rovný díl, složený ze dvou částí, a zadní s průkrčníkem (délka ca $146 \mathrm{~cm}$, šířka ca $50 \mathrm{~cm}$ ). Mezi nimi bylo na každé straně vždy pět klínů (postupně od předního dílu): rovný (délka ca $106 \mathrm{~cm}$, největší šíŕka ca $48 \mathrm{~cm}$ ), symetrický podle středové osy (délka ca $106 \mathrm{~cm}$, největší šířka ca $48 \mathrm{~cm}$ ), dva užší (rozměry rekonstruované z fragmentů, délka ca $106 \mathrm{~cm}$, největší šířka ca $30 \mathrm{~cm}$ ) a jeden s nestejným úhlem sbíhání (délka ca $120 \mathrm{~cm}$, největší šířka ca $48 \mathrm{~cm}$ ). Dochoval se i jeden rukáv, směrem k zápěstí zúžený. Předpokládaná původní délka oděvu je asi $154 \mathrm{~cm}$.

Základ svrchního oděvu opět tvořil přední rovný díl s průkrčníkem (délka ca $133 \mathrm{~cm}$, šiřrka ca $50 \mathrm{~cm}$ ), dva klíny s ,ut’atou špičkou“, které přiléhaly k rovnému dílu (délka ca $103 \mathrm{~cm}$, největší šířka ca $45 \mathrm{~cm}$ ), dva klíny s „ostrou špičkou“ přiléhající ke klínům s ,ut’atou špičkou“ (délka ca $106 \mathrm{~cm}$, největší šířka ca $47 \mathrm{~cm}$ ), dva menší klíny přiléhající ke klínům s „ostrou špičkou“ (délka ca $73 \mathrm{~cm}$, největší šířka ca $18 \mathrm{~cm}$ ) a dva rukávy zakončené do cípů (délka ca $53-58 \mathrm{~cm}$, šířka ca 53-56 cm; Frattaroli 2004, 283-293; Kania 2010, 298-300, 435-437).

Na rekonstrukci P. Frattaroli může být více názorů, např́íklad je otázkou, zda skutečně mezi předním a zadním dílem tuniky bylo pět klínů. Podle autorů tohoto článku rovné pruhy vedle předního dílu mohly být součástí zadního dílu, který se dochoval jenom v horní části. Rozměrově by se tam hodily. Potom by oděvy Cangrande della Scala a Rudolfa I. byly střihově a velikostně velmi podobné.

\subsection{Nohavice}

Zbylé dva lichoběžníkové díly látky s draky a obláčky (č. fragm. 3, 5; obr. 4), umístěné v dřívější rekonstrukci jako předostranové díly surcotu, byly nově interpretovány jako dlouhé nohavice (obr. 11). Oba díly jsou stejně velké a byly střiženy tak, že vzor na jednom směřoval dolů a na druhém nahoru. Po delších stranách jsou stopy po švu, na kratších, hrotitě zakončených, jenom po střižení. Na jednom díle se zachovalo obloukovité zastřižení, dříve určené jako úzký průramek. Ve tvaru nohavic to však byl průstřih pro nárt. Nedochovaly se patní části, původně zřejmě zakulacené, a nártové části. Možná se však nalézají mezi drobnými fragmenty,

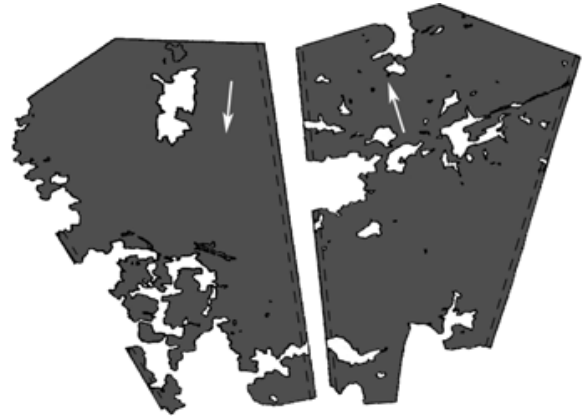

Obr. 11. Nová interpretace tvaru nohavic. Kresba P. Voda. Abb. 11. Neuinterpretation der Beinlinge. Zeichnung P. Voda. po restaurování v Abegg-Stiftung nikam neumístěnými, a nyní uloženými na zvláštním panelu.

Nohavice tedy měly šev na zadní straně nohy, horní lem nebyl začištěn. Obě nohavice byly zrrejmě střiženy najednou ze dvou kusů látky položených na sobě, které zbyly po nastřižení obloukovitě tvarovaných dílů pláště. Odpovídalo by to i opačně položenému vzoru jednotlivých dílů pláště i obou nohavic.

Rozměry (rekonstruované): délka od nártu do hrotitě zakončeného horního lemu ca $73 \mathrm{~cm}$; šiřka horního okraje ca $61 \mathrm{~cm}$.

Ve středověku sahaly nohavice nejméně ke kolenům, pokud byly ještě delší, bývaly často

1 P. Frattaroli jeden oděv interpretuje jako veste manicata a považuje jej za spodní, druhý jako sopravveste, tedy svrchní oděv (2004, 283-293). Naproti tomu K. Kania interpretuje oděvy obráceně - veste manicata považuje za svrchní a označuje jej jako übergewand, naopak sopravveste interpretuje jako tuniku, neboli oberkleidung. Jako podpůrný argument uvádí tvar rukávů a to, že u tuniky jsou rukávy dlouhé, zatímco übergewand má rukávy jenom k lokti a s cípy (Kania 2010, 298-300, 435-437). Autoři tohoto článku přebírají interpretaci K. Kanii. 


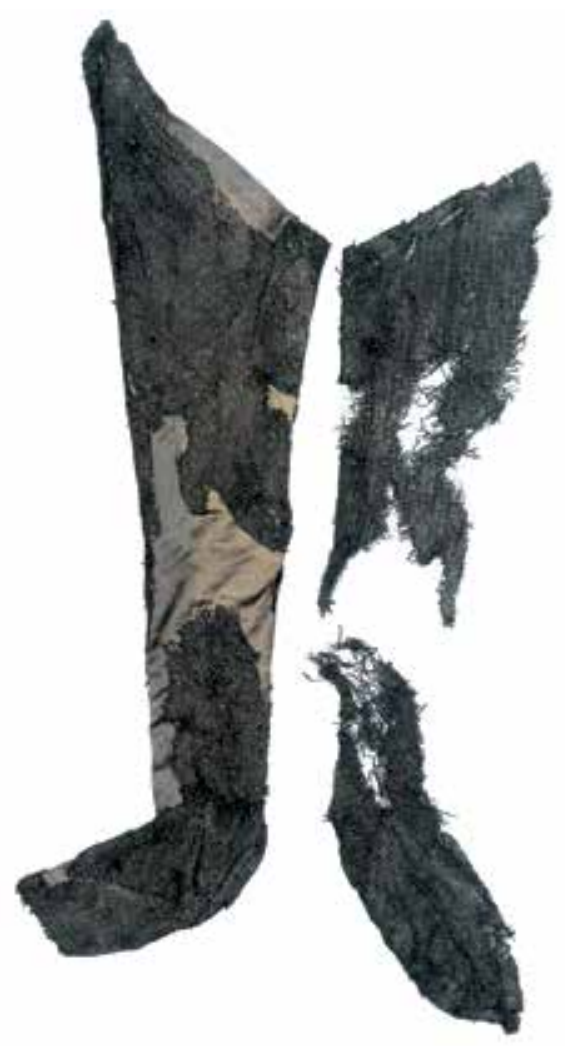

Obr. 12. Nohavice č. 88 z Herjolfsnaes. Podle Østergård 2004, 223.

Abb. 12. Beinlinge Nr. 88 aus Herjolfsnaes. Nach Østergård $2004,223$.

čištěn. Nohavice též nemají patu, chodidlo a špičku, protože není žrejmé, jak vypadaly vorigibyla nová šitá rekonstrukce darována do sbírek Pražského hradu.

\section{Závěrečné odůvodnění nové rekonstrukce}

Lze se domnívat, že Rudolf I. (IV.) Habsburský byl do rakve pohřben v tehdy módním, vypodšívkovaném a precizně ušitém dlouhém a poměrně objemném svrchním, případně základním oděvu s rukávy z látky s ptáky, který mohl nosit ještě za svého života. Pro př́iležitost pohřbu a pro docílení majestátního vzhledu krále zřejmě byly narychlo zhotoveny plášt' a nohavice $\mathrm{z}$ obdobné tkaniny, se vzorem s draky a obláčky. Tyto oděvy nemají podšívku a také jsou ušity ledabyleji.

Dřívější rekonstrukce surcotu a především krátkého a projmutého kabátce neodpovídala charakteristice evropské módy začátku 14. století. Do Čech tato nová móda přišla až nejdříve okolo roku 1330 - např́íklad Petr Žitavský si ve své kronice stěžuje na těsné a krátké oděvy (Petra Žitavského kronika Zbraslavská, 301). V ikonografických pramenech je těsnější a kratší oděv s knoflíky vepředu poprvé vyobrazen v Arabele od Ulricha von dem Türlin v kodexu Willehalm (fol. 63:32r; 1334, Kassel, Stadtbibliothek), fyzicky se dochoval např́íklad kabátec Charlese de Blois, datovaný až do roku 1364 (Lyon, Musée Historique des Tissus). 


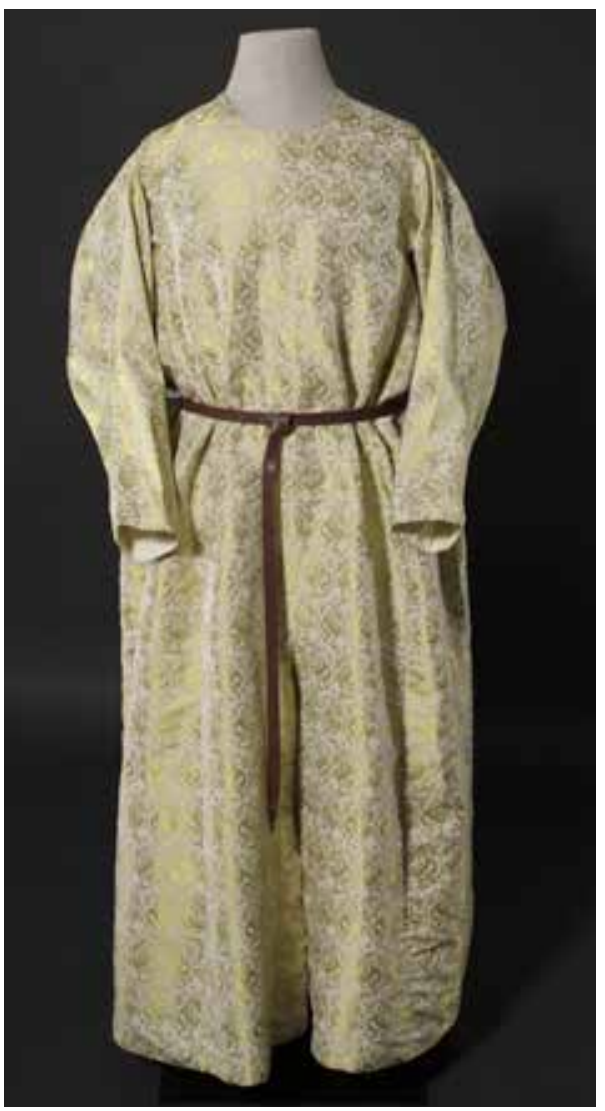

Obr. 13. Nová šitá rekonstrukce podoby oděvu s rukávy a nohavic Rudolfa I. Délka rukávů je vzhledem ke stavu zachování fragmentů diskutabilní. Novodobý opasek byl použit pro představu, jak mohl být také tento oděv nošen. Foto Správa Pražského hradu, Jan Gloc.

Abb. 13. Jetzige genähte Rekonstruktion der Kleidungsform mit langen Ärmeln und Beinlingen von Rudolf I. Die Ärmellänge steht im Hinblick auf den Erhaltungszustand der Fragmente zur Diskussion. Der neuzeitliche Gürtel wurde wegen der Vorstellung benutzt, wie dieses Kleidungsstück ebenfalls hatte getragen werden können. Foto Verwaltung der Prager Burg, Jan Gloc.

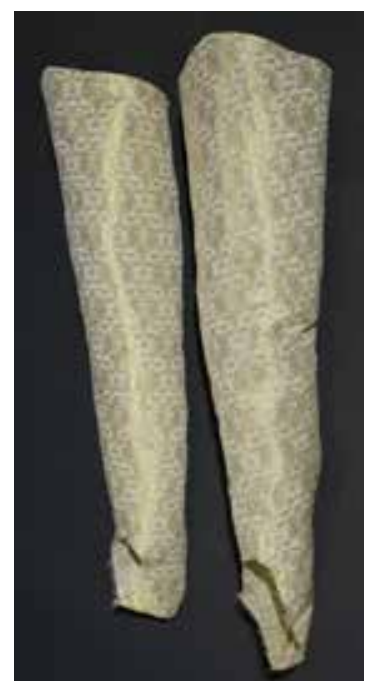

Na začátku 14. století se nosily oděvy ještě dlouhé a poměrně široké. Nová představa o pohřebním rouchu Rudolfa I. tomu lépe vyhovuje. Je však zřejmé, že k vyjasnění některých zůstávajících sporných bodů, především podoby rukávů, by nejvíce pomohlo, kdyby se originální tkaniny sejmuly z panelů a byly podrobeny novému průzkumu. Bylo by žádoucí, aby k tomu $\mathrm{v}$ budoucnosti došlo.

Př́íspěvek byl vypracován s podporou grantového projektu GAČR 19-00166S.

\section{Prameny a literatura}

BAŽANTOVÁ, N. et al., 1993: Bažantová, N.-Bravermanová, M.-Kobrlová, J.-Samohýlová, A.-Wasserbauer, R., Textilie z hrobu Rudolfa I., českého krále, zv. Kaše - Die Textilien aus dem Grab Rudolfs I., des böhmischen Königs sgn. „Kaše“, AH 18, 359-377.

BRAVERMANOVÁ, M., 1997: Pohřební oděv Rudolfa I. Habsburského, českého krále, zv. Kaše. Exkurs do módy začátku 14. století - The funeral Costume of Rudolph I of Habsburg, King of Bohemia (known as the Pie): A Jurney to Fashion at the Beginning of the 14th Century. In: Život $\mathrm{v}$ archeologii středověku (Kubková, J.-Klápště, J.-Ježek, M.-Meduna, P., edd.), 67-84. Praha. 
- 2010: Pohřební oděv Rudolfa I. Habsburského, zvaného Kaše. In: Královský sňatek. Eliška Přemyslovna a Jan Lucemburský - 1310 (Benešovská, K., ed.), katalog výstavy (Praha, Dům u Zvonu, Muzeum hlavního města Prahy, 14. 11. 2010 - 6. 2. 2011), 307-309. Praha.

- 2016: Pražský hrad jako pohřebiště lucemburské dynastie. In: Koruna království - The Crown of the Kingdom. Katedrála sv. Víta a Karel IV. - Charles IV and the Cathedral of St. Vitus (Bravermanová, M.-Chotěbor, P., edd.), publikace k výstavě (Praha, Jízdárna Pražského hradu, 15. 5. - 28. 9. 2016), 78-114. Praha.

BRAVERMANOVÁ, M. (ed.), 1996: Pohřební výbava českého krále Rudolfa. Nejstarší Habsburkové na Pražském hradě. Katalog výstavy (Praha, Starý královský palác Pražského hradu, 16. 1. - 12. 5. 1996). Praha.

BRAVERMANOVÁ, M.-FLURY-LEMBERG, M., 2004: Il corredo funebre di Rudolfo I re Bohemia. In: Cangrande della Scala. La morte e il corredo di un principe nel medioevo europeo (Marini, P.-Napione, E.-Varanini, G. M., edd.), katalog výstavy (Verona, Museo di Castelvecchio, 23. 10. 2004-3. 1. 2005), 295-298. Venezia.

BRAVERMANOVÁ, M.-VODA, P., 2011: Pokus o určení střihu pohřebního oděvu Rudolfa I. Habsburského zvaného „král Kaše“. Nepublikovaná zpráva, ulož. v dokumentaci oddělení uměleckých sbírek Správy Pražského hradu, inv. č. PHA 49.

- 2017: New discovery about the funerary garment of Czech king Rudolph I. (IV.) Habsbourg (died 1307). In: Archaeological Textiles - Links Between Past and Present. NESAT XIII. (Bravermanová, M.-Březinová, H.-Malcolm-Davies, J., edd.), 349. Liberec - Praha.

FLURY-LEMBERG, M.-ILLEK, G., 1995: Der Grabornat König Rudolphs I. von Böhmen. Spuren Kostbarer Gewebe. Riggisberger Berichte 3, 174-199. Abegg-Stiftung.

- 1995a: Grabornat König Rudolphs von Böhmen. Nepublikovaná restaurátorská zpráva, ulož. v dokumentaci oddělení uměleckých sbírek Správy Pražského hradu, inv. č. PHA 49.

FRATTAROLI, P., 2004: Il corredo funebre di Cangrande. In: Cangrande della Scala. La morte e il corredo di un principe nel medioevo europeo (Marini, P.-Napione, E.-Varanini, G. M., edd.), katalog výstavy (Verona, Museo di Castelvecchio, 23. 10. 2004 - 3. 1. 2005). Venezia, 283-293.

HERGET, M. (ed.), 2011: Des Kaisers letzte Kleider. Neue Forschungen zu den organischen Funden aus den Herrschergräbern im Dom zu Speyer. Historisches Museum der Pfalz Speyer. Speyer.

KANIA, K., 2010: Kleidung im Mittelalter. Materialien-Konstruktion-Nähtechnik. Ein Handbuch. Köln Weimar - Wien.

LUACES, J. Y.-VALLE PÉREZ, J. C., 2005: Vestiduras ricas. El Monasterio de las Huelgas y su época 1170-1340, katalog výstavy (Madrid, Palacio Real de Madrid, 16. 3. - 19. 6. 2005). Madrid.

MARINI, P.-NAPIONE, E.-VARANINI, G. M. (edd.), 2005: Cangrande della Scala. La morte e il corredo di un principe nel medioevo europeo, katalog výstavy (Verona, Museo di Castelvecchio, 23. 10. $2004-$ 3. 1. 2005). Venezia.

ØSTERGÅRD, E., 2004: Woven into the Earth. Textiles from Norse Greenland. Aarhus.

PILNÁ, V., 2017: Střihová řešení oděvů lucemburského období a jejich experimentální užití. In: Oděv a textil v životě člověka doby lucemburské. Sborník příspěvků ze specializované konference, uspořádané Národním památkovým ústavem, územním odborným pracovištěm středních Čech v Praze 6. října 2016 (Nachtmannová, A.-Klapetková, O., edd.), 108-121. Praha.

Petra Žitavského Kronika zbraslavská. Fontes rerum bohemicarum IV., J. Emler (ed.). Praha 1884.

VODA, P., 2017: Rekonstrukce pohřebního oděvu krále Rudolfa I. Habsburského zvaného král Kaše. In: Sborník semináře historie odívání v Hradci Králové (Burianová, M., ed.), 51-71. Hradec Králové.

\section{Zusammenfassung}

Eine Neurekonstruktion des Grabgewandes von Rudolf I. (IV.) von Habsburg, genannt König Brei

Das Grabgewand des böhmischen Königs Rudolf I. (IV.) von Habsburg († 1307) wurde im Jahr 1991 einer Tumba in der Königskrypta des Veitsdoms auf der Prager Burg entnommen. Die Stofffragmente wurden im Atelier der Werner Abegg-Stiftung in Riggisberg restauriert. Das Gewand wurde aus zwei webtechnisch ähnlichen Lampas genäht, die aus Mittelasien und von der Wende des 13. und 14. Jahrhunderts stammen. Auf dem ersten Stoff befinden sich Vögel, die einen Zweig oder Fisch im Schnabel halten, auf dem zweiten sind chinesische Drachen 
und Wölkchen. Das Muster wurde mit einem Schussfaden gewebt, der aus Streifen tierischen Ursprungs (Leder) hergestellt wurde, die auf der Außenseite vergoldet und auf der Innenseite versilbert waren.

Nach der Restaurierung wurde die Form des Gewandes rekonstruiert und seine Einzelteile auf Holzplatten ausgelegt, die mit einem speziellen Stoff bespannt waren. Die Platten wurden dann mit Glas abgedeckt. Das Gewand bildete entsprechend dieser Rekonstruktion einen halbellipsenförmigen, aus vier mit Drachen und Wölkchen versehenen Stoffstreifen genähten Mantel, in die Schleppe wurden von der Unterseite zwei mit Vögel versehene Stoffstreifen eingesetzt. Der ärmellose bis über die Knie reichende kurze Surcot war aus drei Teilen geschnitten. Das schmale trapezförmige Rückenteil wurde aus dem Stoff mit den Vögeln zusammengefügt, aus dem Stoff mit den Drachen und Wölkchen wurden zwei Teile mit tropfenförmigen Ärmellöchern geschnitten, die gleichzeitig die Taillen und das Brustteil des Kleidungsstücks bildeten, und zwar so, dass das Muster auf einem Teil nach oben und auf dem zweiten nach unten zeigte. Von dem Stoff mit den Vögeln wurde auch ein kurzes tailliertes Wams mit schmalen bogenförmig geformten Ärmellöchern genäht. In diese wurden die Ärmel mit trapezförmigem Ärmelkopf eingesetzt, ein unregelmäßiger trapezförmiger Keil sollte gewährleisten, dass sie in das Ärmelloch eingepasst werden können. Surcot und Wams hatten ein Futter aus dem gleichen Material, der Mantel war nicht gefüttert. Zum Schluss der Restaurierung wurde eine Nachbildung der Kleidung angefertigt.

Das so entstandene Aussehen der Kleidung entspricht jedoch nicht den schriftlichen und ikonographischen Quellen, in denen die Mode vom Anfang des 14. Jahrhunderts dokumentiert wird. Vor allem hat man damals noch kein so kurzes und tailliertes Wams getragen, dessen Aufkommen erst in die dreißiger Jahre des 14. Jahrhunderts datiert wird. Auch der Schnitt des Surcots ist untypisch und nicht passgerecht für die menschliche Figur. Aus diesem Grund kam es zu dem Versuch einer Neurekonstruktion der Bekleidungsteile.

Mit den Originalstoffteilen konnte nicht gearbeitet werden, weshalb als Vorlage vor allem die bei der Restaurierung in der Abegg-Stiftung angefertigte Foto- und Zeichendokumentation herangezogen wurde. Von allen Einzelfragmenten der gemusterten Stoffe sowie der Futter wurden aus Papier Modelle in Originalgröße ausgeschnitten. Jedes dieser Papiermodelle wurde mit einem Großbuchstaben und einer Ziffer gekennzeichnet. Dann wurde der genaue Verlauf der Ränder, die festen Ränder, Schnittspuren, Falten, Knicke, Nahtlöcher und in welcher Richtung der Stoff geschnitten war auf ihnen aufgezeichnet.

Der Schlüssel zur Zusammenfügung der Neurekonstruktion der Form sind einerseits die Winkel, unter denen die Schnittränder der trapezförmigen Teile zusammenlaufen sowie die Neigung dieser Ränder gegenüber dem Schuss des Gewebes und andererseits die Feststellung, dass die einzelnen Teile der Kleidung bei der früheren Rekonstruktion aus mehreren Fragmenten zusammengesetzt wurden, deren Ränder man nacheinander so eingesetzt hat, sodass der Eindruck entsteht, sie bildeten ein Ganzes. Bei der jetzigen Rekonstruktion wurde im Hinblick auf das gleiche Material so mit den Fragmenten gearbeitet, als ob es sich ursprünglich um ein Futter gehandelt habe.

Der Mantel hatte eine halbellipsenartige Form, die sich aus vier vertikal gelegten Streifen aus dem Stoff mit Drachen und Wölkchen zusammensetzt und im Bereich der Schleppe bogenförmig geschnitten war. In die Schleppe war jedoch kein weiterer Stoff eingesetzt worden. Zwei übrig gebliebene Stoffstreifen mit Vögeln, die nicht wie die übrigen Mantelteile am Ende $\mathrm{zu}$ einem Bogen geschnitten sind, wurden bei der Rekonstruktion des anderen Kleidungsteils verwendet.

Dabei handelt es sich um ein langes Kleidungsstück mit Ärmeln, das sich aus einem geraden Vorder- und Rückenteil zusammensetzt. Zwischen diesen Teilen befanden sich auf jeder Seite drei trapezförmige Keile, die vom Ärmelloch bis zum unteren Rand reichten. Das Vorderteil hatte vorne noch einen kürzeren Schlitz, in den zwei schmale dreieckförmige Keile eingesetzt wurden. Die Ärmel setzten sich aus drei Teilen zusammen, wodurch die Ausformung des Schulterkopfes erreicht wurde. Die Länge der Ärmel und damit auch der Unterkleidung sind 
diskussionsträchtig, die erhalten gebliebenen Fragmente des gemusterten Stoffes und auch des Futters erlauben es nicht festzulegen, ob sie ursprünglich $3 / 4$ war oder bis zum Handgelenk reichte. Das ganze Kleidungsstück wurde mit Seidenstoff gefüttert, der in vielen Fragmenten erhalten geblieben war, die wichtig waren, um den Schnitt des Kleidungsstückes bestimmen zu können. Hinsichtlich dessen, dass sich Länge und Umfang des unteren Saums nicht genau rekonstruieren lassen, kann nicht festgelegt werden, um welchen Kleidungstyp es sich genau gehandelt hat. Es bieten sich zwei Möglichkeiten an - ein Surcot mit Dreiviertel-Ärmeln, möglicherweise eine Cotte mit langen Ärmeln. Die letztendliche Form des Kleidungsstückes ähnelt sehr der Oberkleidung und dem Übergewand des in Verona beigesetzten Cangrande della Scala († 1329).

Die übrig gebliebenen Stoffteile mit den Drachen und Wölkchen, die bei der früheren Rekonstruktion als vorderseitige Oberkleidungsteile appliziert wurden, können als lange Beinlinge interpretiert werden. Die Teile des Spanns sind nicht erhalten geblieben, der obere Rand war nicht versäubert. Ihre Form ähnelt sehr den in Herjolfsnaes entdeckten Strümpfen Nr. 88.

Die letztendliche Form des Kleidungsstückes wurde anhand von ikonographischen Quellen und erhalten gebliebenen mittelalterlichen Kleidungsstücken verifiziert. Von dem Kleidungsstück und den Beinlingen wurden ebenfalls Repliken genäht.

Man kann demnach annehmen, dass Rudolf I. (IV.) von Habsburg in einer ausgefütterten und präzise aus dem Stoff mit den Vögeln genähten Kleidung im Sarg bestattet wurde, die damals in Mode war und noch zu seinen Lebzeiten von ihm getragen werden konnte. Anlässlich des Begräbnisses und um ein majestätisches Aussehen des Königs zu erzielen, hat man dann aus einem ähnlichen, jedoch mit einem Drachen- und Wölkchenmuster versehenen Stoff noch schnell einen Mantel und Beinlinge angefertigt.

Der vorliegende Beitrag wurde im Rahmen des Förderprojektes GAČR 19-00166S ausgearbeitet.

PhDr. Milena Bravermanová, Archeologický ústav AV ČR, Praha, v. v. i., Letenská 4, Praha 1, Česká republika, milena.bravermanova@seznam.cz

PhDr. Helena Březinová, PhD., Archeologický ústav AV ČR, Praha, v. v. i., Letenská 4, Praha 1, Česká republika,brezinova@arup.cas.cz

Mgr. Petr Voda, soukromý badatel, Česká republika, OK1IPV@seznam.cz 
